\title{
The post-Late Pontian paleogeographic evolution of the south Harghita Mountains area and the adjacent basins
}

\author{
Attila LÁSZLÓ \\ Nicolae Iorga 10/A. 520089, Sfântu Gheorghe, Romania \\ Received 12 March 2004; accepted 10 July 2005
}

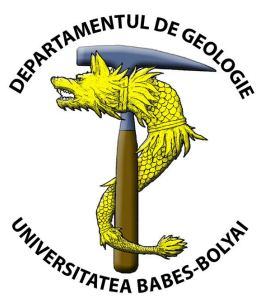

\begin{abstract}
The paper concerns the stages of evolution of the South Harghita area and of the adjacent mountainous basins. The focus is set on specific geological events and on their consequences upon the paleogeographical modeling. Based on field observations and on previous studies, the Pliocene-Pleistocene geological events from the Baraolt and Lower Ciuc basins, the Tuşnad - Malnaş Channel and Sfântu Gheorghe gulf were synchronised with those from the South Harghita volcanic area.
\end{abstract}

Key words: Paleogeography, Pontian - Pleistocene, Baraolt - South Harghita - Ciuc area, Tuşnad - Malnaş Channel

\section{INTRODUCTION}

During the last $5-6$ million years $(\mathrm{Ma})$ the area between the East-Carpathian flysch and the southeastern border of the Transylvanian Basin was the most active one within the Eastern Carpathian Mountains concerning the tectonic mobility. The main cause was represented by the regional tectonic framework, which led to major paleogeographical changes.

Most of the events with paleogeographical implications took place in the South Harghita Massif and its adjacent areas (intermountain-basins).

This paper presents a synthesis of the corresponding geological events according to various stages between the end of Pontian and the Late Pleistocene.

The study is based on the correlation of the geological data on the South Harghita volcanic area with that on the neighbouring regions (Baraolt and Ciuc basins, Olt Channel), especially in the contact areas with sedimentary rocks.

Thus it was proved that the adjacent units are genetically synchronous, and closely related to the paleogeographical evolution of the South Harghita volcanic area (Fig. 1).

The results of previous scientific research in the region, on morphology, hydrology, orography, stratigraphy of the sedimentary deposits in the intramontaineous basins, disjunctive tectonics and its progress during the Pliocene Pleistocene, correlations between geological formations, radiometric ages of the volcanic rocks, sequences of petrotypes within various volcanic structures, and postvolcanic phenomena, were taken into account as a background for the present study.
The most significant papers on the studied region belong to Bányai $(1922,1927,1929,1932)$, Atanasiu (1939), Treiber (1953, 1973), Török, (1956a, 1956b, 1959), Kristó (1955, 1957, 1972a, 1972b, 1974, 1980, 2003), Gheorghiu (1956), Székely (1959), Pop (1960), Liteanu et al. (1962), Bandrabur (1963, 1971), Bandrabur \& Roman (1972), Airinei et al. (1965), Iancu (1965a, b, 1972), Rădulesco et al. (1965), Rădulesco \&.Kovács (1966), Rădulesco \& Kisgyörgy (1970), Rădulesco \& Samson (1985), Rădulescu \& Samson (1995), Patrulius \& Mihăilă (1966), Rădulescu (1968a, b, 1973), Rădulescu \& Peltz (1968, 1970, 1973), Rădulescu et al. (1973), Samson \& Rădulesco (1969, 1973), Samson et al. (1969, 1971), Peltz (1970a, 1970b, 1971a, 1971b), Peltz et al. (1987), Casta (1971, 1980), Coteț (1971), Schreiber (1972, 1980, 1994), Tövissi (1972, 1974, 1997), Băicăințan (1981), Michailova et al. (1983), Kusko (1984), Savu et al. (1978), Savu 1984), Szakács (1986, 2000), Szakács \& Seghedi (1995a, 1995b, 1998), Szakács et al. (1984, 1993, 1994), Andreescu et al. (1987), Karátson (1990), Karátson et al. (1992), Pécskay et al. (1992, 1995, 2003), Juvigné et al. (1994), Moriya et al. (1996).

Several papers discussed the paleogeography of some sectors in the Baraolt - Harghita Mountains - Ciuc Basin during various time intervals within the Pontian, Pliocene and Quaternary. They represent the main references for the current study.

Among these papers one can mention Szádeczky (1929), Bulla (1948), Rădulescu (1968), Rădulescu \& Peltz (1970), Peltz (1970a), Bandrabur et al. (1972), Kristó (1972a), Tövissi (1972), László et al. (1997, 2001), László (1999b, 2000a, b).

Detailed paleogeographical information is included in several papers by László (1999a, b; 2000b; 2001; 2003), 


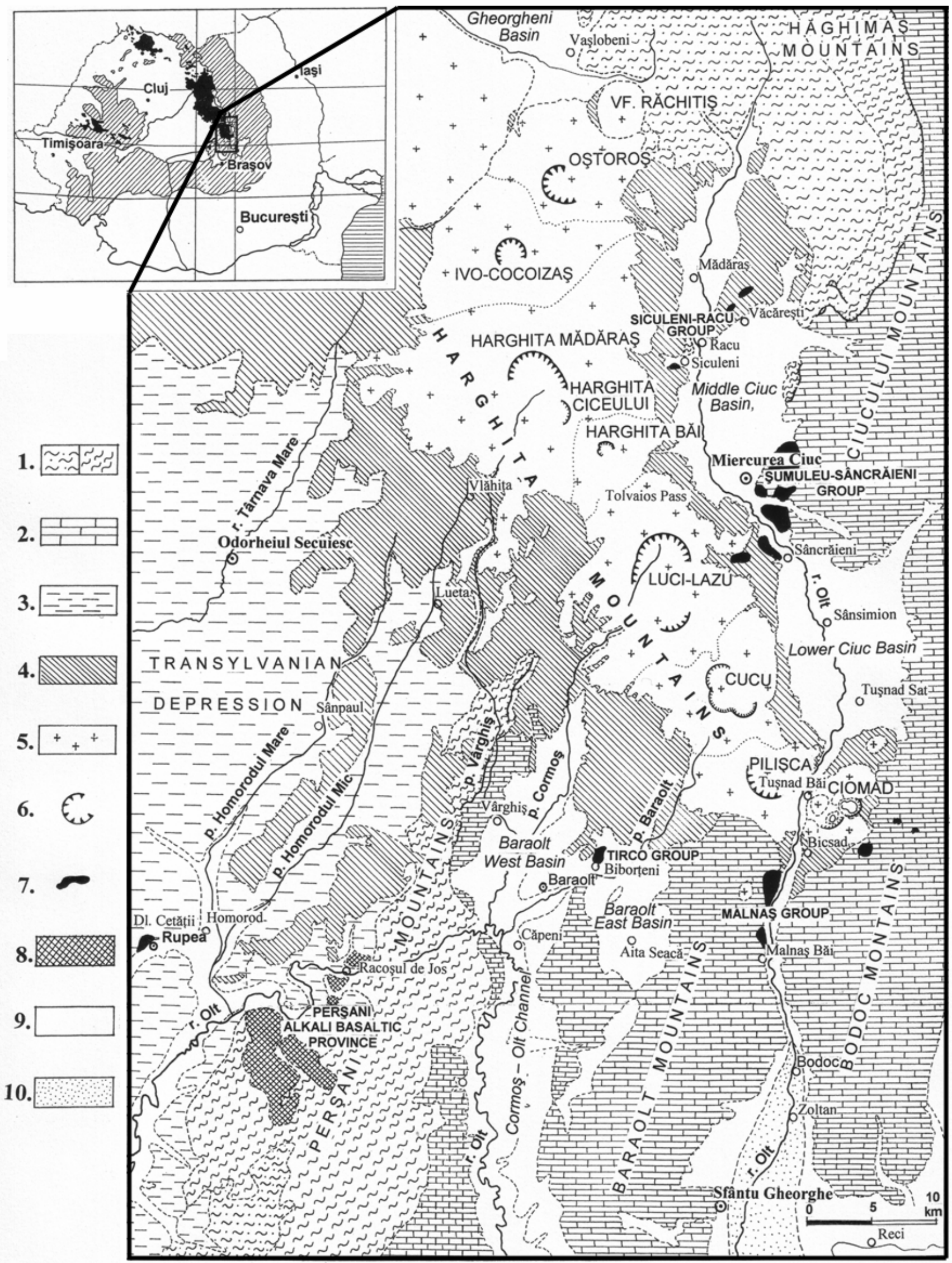

Fig. 1. Geological sketch with the location of Harghita Mountains and the adjacent areas (Baraolt Basin, Ciucurilor Basin, TuşnadMalnaş Channel, Perşani Mountains, Baraolt Mountains, Bodoc Mountains, and Transylvanian Depression.

1. Crystalline-Mesozoic belt (East Carpathians); 2. Internal Flysch Zone (Ceahlău Nappe) (East Carpathians); 3. Miocene sedimentary deposits (Transylvanian Depression); 4. Volcanoclastic deposits; 5. Volcanic structures of the Harghita Mountains, 6. Craters and calderas of the main volcanic structures in Harghita; 7. Small-sized peripheral magmatic structures; 8. Alkaline volcanism (Perşani Mountains); 9. Molasse deposits of the intramontaineous basins; 10. Pleistocene psamitic-psefitic deposits of volcanic and sedimentary origin (Sfântu Gheorghe area). 
László \& Dénes (1996, 1998), László \& Kozák (1998a, b; 2003), László et al. (1995, 1996, 1997).

\section{PALEOGEOGRAPHICAL RECONSTRUCTION OF THE PONTIAN - EARLY PLIOCENE}

The paleogeographical reconstruction of the area during the Pontian, and the Pontian-Pliocene limit was acquired by using radiometric ages obtained on volcanic rocks, correlated with the distribution of volcanoclastic formations in Baraolt basin and the tectonic evolution of the studied area (László et al. 1997, 1999a, b, László \& Kozák 1998a, b, 2003, and László 2003) (Fig. 2 and profile in Fig. 6).

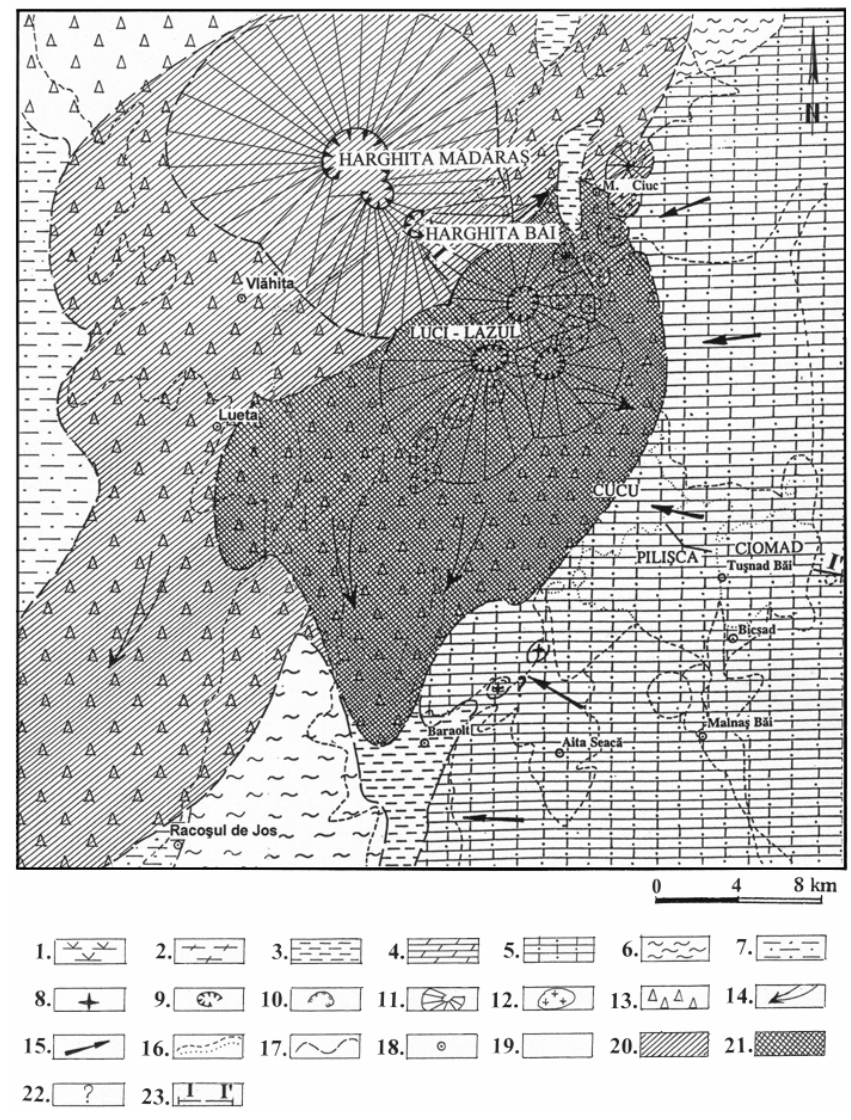

Fig. 2. Paleogeographical sketch of the South Harghita area and the adjacent areas at the beginning of Pliocene.

1. Quaternary swamp deposits; 2. Lacustrine environment with formation of specific deposits (Geyserite, Opal, Diatomite,

Pumice); 3. Lacustrine environment with formation of sediments and volcanoclastic deposits; 4.Pliocene-Pleistocene synvolcanic and postvolcanic sediments; 5. Cretaceous sediments of the Flysch zone of East Carpathians; 6. Crystalline-Mesozoic Zone of East Carpathians; 7. Miocene sedimentary deposits (Transylvanian Depression); 8. Volcanic structures without crater; 9. Crater;

10. Collapse caldera; 11. Stratovolcanic cone; 12. Volcanic domes; 13. Volcanoclastic deposits; 14. The erosion direction of the volcanic deposits; 15 . The erosion direction of the sediments deposits; 16. Present geological limits; 17. Geological limits; 18. Locality; 19. The inactive area of the volcanic chain; 20. The active area of the volcanic chain (First stage); 21. The active area of the volcanic chain (Next stage); 22. uncertainty; 23. Location of the cross-sections.

In the northern part of Harghita, the first event is represented by the emplacement of small magmatic structures along north, north-east - south, south-western alignments within the metamorphic domain (the CrystallineMesozoic Unit). Examples are provided by the intruzive magmatic bodies in the Siculeni-Racu-Văcăreşti area. The other intrusive structures (southwards), that have been evidenced by geophysical investigations (Clain et al., 1978, 1980, with the author's permission, Ionescu et al., 1984, 1988), were subsequently covered by a huge pile of volcanoclastics resulted from the volcanic activity of the subsequently-formed statovolcano Mădăraş.

At the end of the Pontian (6,0 - 5,4 Ma.), a paroxysmal volcanic activity was recorded in Harghita Mădăras area (North Harghita) (Peltz, 1987; Pécskay et al., 1995). To this stage, the thick piles of volcanoclastics from Homoroadelor area and the upper Vârghiş valley can be attributed (Fig. 1 and 2). It can be assumed that these deposits were even more extended eastwards from the present day volcanic alignment. However, the sector located eastwards from the Crystalline-Mesozoic Unit had higher altitudes than the metamorphic unit, thus the unconsolidated, loose volcanoclastics deposited along its surface could have been easily washed away and resedimented in an area located westwards, but still at the eastern and southern borders of the volcanic structure. This process took place right after the formation of the volcanoclastic deposits, at the end of Pontian - beginning of Pliocene.

Undoubtedly, the general direction of flow of the hydrographic catchment was from east to west, towards the Transylvanian Depression. The valleys located in the flysch area (the eastern part of the studied area) that flow from east to west - geomorphologically more evolved as compared to the valleys cut within the sedimentary basins also plead for the previous statement. Erosional markers of the volcanoclastic formation are still present westwards from the volcanic chain, i.e. north from Vârghiş village, within the Perşani Mountains. This is a proof for the initial extension of the volcanoclastics also in this region.

The turning point in the evolution of the area is related to the enhancement of tectonic movements along the EastCarpathians structures, in the eastern border of the Crystalline-Mesozoic Unit. The increased mobility of the region can be demonstrated by the debut of volcanic activity east from Perşani Mountains, along tectonic alignments parallel with the overthrust plane located between the Crystalline-Mesozoic and flysch domains. The active tectonics, led to the formation of the small volcanic structures along the Şumuleu - Jigodin - Sâncrăieni - Harom alignment (Fig. 1), and by the partial reactivation of the Siculeni-Racu-Văcărești area. The reactivation of the intrusive structures can be proved by the existence of various intrusive rock types generated during different time intervals, as shown by their structural relationships. In our opinion, all these volcanic centres are synchronous with the magmatic structures from Tirco area and from the infrastructure of the Luci - Lazu volcanic edifice, being displayed along the same tectonic alignments or along parallel ones. The radiometric ages (Peltz et al., 1987; Pécskay et al., 1995) prove that the volcanic centres (Tirco, Şumuleu, Harom) and the intrusive magmatic bodies (Sâncrăieni) have been active during the Pontian (6.8-5.9 $\mathrm{Ma})$ and the Pontian - Dacian boundary $(5.9-5.13 \mathrm{Ma})$. However, the sinking of the areas in front of the CrystallineMesozoic Unit and the deposition of molasse formations in the adjacent intramontaineous basins can be related only to a new stage of tectonic reactivation, that also lead to a subsequent stage of intense volcanic activity (Ciuc Basin 4.3 Ma, Racu - 4.9 Ma, Tolvaioş Peak - 4.8 Ma, Tolvaioş 
Pass - 4.3 Ma, Tirco - 4.8 Ma) (Peltz et al., 1987; Pécskay et al., 1995, 2003; László et al., 1996, 2003).

The lower volcaniclastic level - occurring in the Baraolt Basin - represents another criterion for establishing the timing of the paleogeographical change in the studied region. (László \& Kozák, 1998a, Fig. 5A). This level is located in the lower part of the basal breccia within the sedimentary formation in the Baraolt Basin (László \& Kozák, 1998a). It was deposited in a fluviatile-lacustrine environment that was established as a first stage in the evolution of the sedimentary basin (László \& Kozák, 1998a). The lower volcanoclastic level occurs as a northsouth elongated unit at the eastern boundary of the Crystalline-Mesozoic Unit; basically it overlaps the Cormoş - Olt major tectonic alignment (the central-east Carpathian outline). The source-area was the northern sector of Harghita and the source material is represented by the volcanic products generated during the first paroxysmal stages of Luci structure. Most of them are debris flows (Szakács \& Seghedi, 1995), originating from Harghita Mădăraş sectors. Genetically, the level can be correlated with the Vlăhița - Chirui volcano-sedimentary formation introduced by Peltz (1971b).

According to the data on the youngest volcanic materials constituting the lower volcanoclastic level, one can assume its age as being between $4.3-4.9 \mathrm{Ma}$. This interval is consistent with the mammal fauna geochronology (Samson et al. 1969, 1995) which was identified above the lower volcanoclastic level and within coal layer III, attributed to the Charnotian.

In the same time, the spatial development of the lower volcanoclastic level proves the intermittent sinking of the Ciuc - Harghita - Baraolt depressionary area, located on the eastern border of the Crystalline-Mesozoic Unit. The first alignment that sunk was overlapping "the central eastCarpathian line", i.e. Middle Ciuc Basin - Cormoş alignment - Olt sectors of the eastern border of Perşani Mountains (Fig. 1 and 2). The sinking delay registered by the compartments along the next eastwards tectonic alignments, parallel to the Cormoş-Olt line can be documented by the spatial development of coal layer I from Baraolt Basin. The coal layer I is missing from the eastern sectors of the basin. Thus, a lacustrine environment with clayey-sandy sediments was established northerly (Middle Ciuc Basin), while south from the volcanic area (Luci Lazu) a fluviatile-lacustrine one was present. The volcanic material was transported from the higher areas of Mădăraş volcanic structure and from the western slopes of Luci structure. This new setting had completely changed the regional paleogeography, leading to the formation of a new hydrographic system. Previously, the main river that collected all the South Harghita and Baraolt sources had a general north-south orientation, along Cormoş alignment, and flew towards the lower Bârsa Basin.

Again, the spatial distribution of the lower most volcanoclastic level is used as an argument (László \& Kozák, 1998a, Fig. 5A).

From an orographical point of view, crests and chains parallel to the east-Carpathian orogen formed during this interval, by the reactivation of older tectonic systems.

The newly installed hydrographic regime will display the present-day orientation of Cormoş, Vârghiş, Homoroadelor valleys, and of the upper course of Târnava Mare valley (Fig. 1).

\section{PALEOGEOGRAPHICAL INFORMATION ON THE PLIOCENE EPOCH}

Several distinctive stages of geological events could be separated after the establishment of the paleogeographical setting at the beginning of Pliocene.

Based on radiometric ages (Peltz et al., 1987; Szakács et al., 1994) as well as on the lithological columns of the basins in the neighbourhood of the main volcanic alignment (László \& Kozák, 1998a, Fig. 4) it can be concluded that the main volcanic alignment was relatively calm. Synchronously, the Baraolt - Harghita - Ciuc area continued to sink along normal north-east - south-west faults. This fault system was gradually activated towards south-east.

Concomitantly with the relative calm stage established in the main volcanic alignment, the volcanic activity continued along the north-east - south-western alignments, where small magmatic bodies (intrusive and extrusive) formed. These bodies consist almost exclusively of basaltic andesites, pyroxenic andesites with hypersthene, or pyroxenic andesites \pm hornblende. Such effusive structures are present in Siculeni - Racu - Văcărești area, Cetăţii Hill (Rupea), Şumuleu - Spitalului Hill - Sâncrăieni group, and the effusive Tirco structures group, located along the western border of the internal flysch unit. Based on geophysical data, a series of such structures was also evidenced in the infrastructure of the Cucu stratovolcano (Clain et al., 1978, 1980, Ionescu et al., 1984, 1988).

During the Pliocene, the Ciuc - Harghita - Baraolt depressionary area gradually reached the maximum extent (Fig. 3 and profile in Fig. 6).

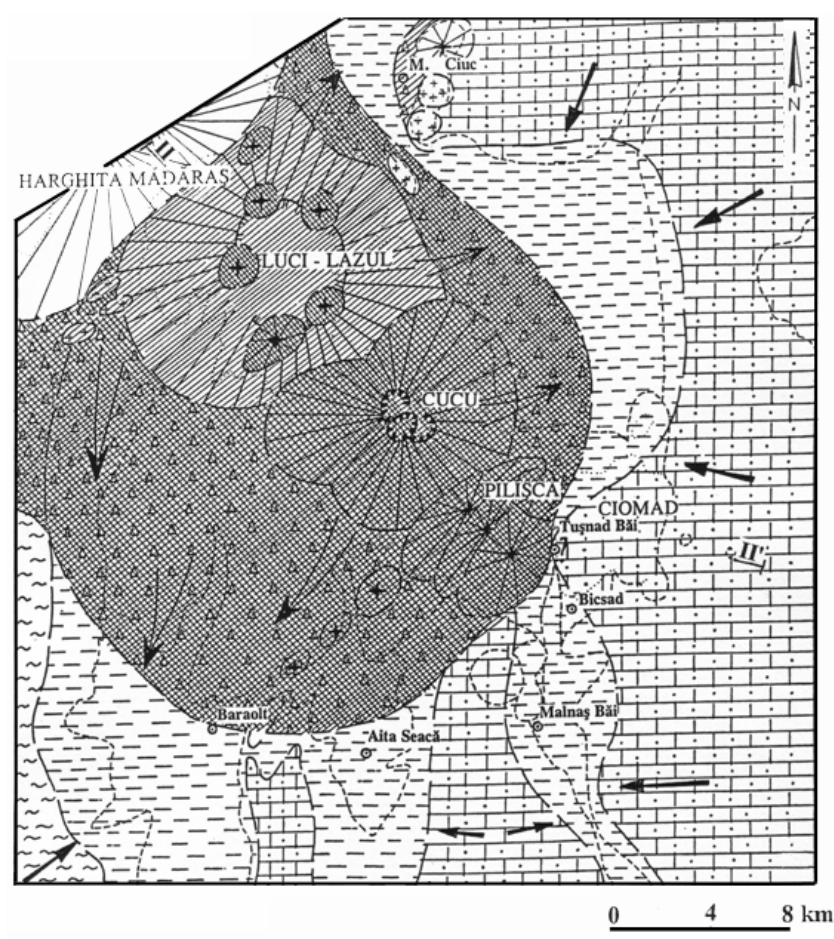

Fig. 3. Paleogeographical sketch of the South Harghita area and the adjacent areas during the Pliocene (Dacian-Romanian boundary). Same legend as for Fig. 1.

Its formation was the result of a process involving a permanent equilibrium between the sinking vs. the sedimentation rates. Arguments for this statement are: a similar grain-size distribution, and petrographic homogeneity of the sedimentary deposits in the newly 
formed basins on both slopes of the volcanic alignment. During the paroxysmal stages of the volcanic chain, the volume of volcanoclastic material sedimented in the neighbouring basins increased, leading to the partial basin filling over extended areas and to the (local) formation of peat-bogs and coal.

The age of the lower marly formation was defined based on Charnotian mammal fossils (Castor praefiber (Depéret) and Boreofiber capeniensis (Rădulescu \& Samson, 1985) between 3.0 - 3.9 Ma (Rădulescu \& Samson, 1995; László, 2000). We attribute the lower part of the sedimentary deposits in Baraolt Basin to the Late Dacian, considering that the Dacian - Romanian boundary is located at 3.6 Ma. In the same time, the radiometric age of formation of the Tirco effusive structure - situated on the first marly horizon - is also 3.6 Ma (László et al., 1997). However, other radiometric ages of volcanic rocks from the middle volcanoclastic complex, also sitting on the marls, point to 3.4 Ma (Casta, 1980).

In a synthesis of magnetostratigraphic measurements on Medium-Late Pliocene and Pleistocene deposits from Romania, Andreescu et al. (1987) indicate an age around 4.0-3.6 Ma for the marly complex between Căpeni and Vârghis.

Under these circumstances, at the end of Dacian beginning of Romanian, the Baraolt and Ciuc Basins were characterised by lacustrine environments during their maximum extent stage, connected through Olt Channel towards the Bârsa Depression. The lake sediments in the Baraolt and Ciuc Basins show a distal facies - characterised by marly deposits containing variable amounts of volcanic tuff, and a proximal facies - with sands, clays, lumachell, and locally carbonate rocks.

The terrigenous supply was dominantly provided by the Crystalline-Mesozoic, and the eastern areas of the emerged flysch units respectively. The volcanic supply is quantitatively subordinated and occurs as volcanic and tuffitic materials within the marly deposits. In the northern area of Baraolt Basin several interlayers of andesitic sands, tuffs, cinerites and volcanic lapilli crop out.

Ciuc Basins shows a different sedimentary pattern, with a source area located in the eastern flysch units, higher in altitude. This is a dominant feature of sedimentation during this interval. The deposits consist of marls containing frequent clay interlayers, sandy clays, fine micaceous sands, coarse quartz- or carbonate-rich sands, pebbles and thin coal interlayers, or material of volcanic origin. Such a lithological succession suggests a relative higher instability of the eastern sector due to the tectonic movements on the one hand, and the changes in the intensity of volcanic activity on the other hand.

The beginning of the Romanian marked a distinctive stage in the paleogeographical evolution of the area. The volcanic activity along the main South Harghita alignment was reactivated forming stratovolcanic structures. A paroxysmal stage marked the beginning of these volcanic events, representing the most intense activity in South Harghita. A huge amount of volcaniclastics was generated, as the second volcaniclastic marker, extended beyond the boundaries of the Baraolt-Harghita-Ciuc area.

In the median sector of this area (oriented northwest southeast), the emerged main volcanic alignment was established. In the stratovolcanic structures the pyroclastic material dominated followed by lava flows (Bányai, 1929,
Rădulescu, 1968a, Török, 1956a, 1956b). The outlines of the Luci structure were completed and Cucu and Mitaci cones were shaped. The main volcanic structures formed at the intersections of the north - south with the northwest southeast tectonic alignments, as central - type stratovolcanoes.

As a result of this paroxysmal volcanism, a large amount of volcanoclastics (volcanic breccias, lapilli, tuffs, bombs) and their reworked products were deposited in Baraolt Basin, giving birth to the middle volcaniclastic complex (László \& Kozák 1998a, b). These deposits also outcrop near the eastern border of South Harghita, being characterized by a larger amount of epiclastic and detrital sedimentary interlayers (Fig. 3 and profile in Fig. 6).

The material transported from the median volcanic alignment towards the two basins clearly dominated the sedimentation process in Baraolt and Ciuc depressionary area.

During the subsequent stage, some parts within the basins recorded limnic conditions when coal could form, followed by a new stage characterised again by marly deposits. Synchronously a constant volcanic activity of reduced intensity, furnished a large amount of volcanic tuffs and tuffites, found within the whole marly succession.

Following the first volcanic paroxysm in South Harghita, intense postvolcanic activity generated iron mineralizations, opal deposits, and geyserite formations in Lueta-VlăhițaChirui area. The postvolcanic events took place during short interparoxysmal stages and concomitantly with the evolution of volcanism in the neighbouring sectors.

The materialisation of the median volcanic chain involved a major change of the Baraolt-Harghita-Ciuc area landscape, with the separation of two distinctive river basins on both sides of the volcanic alignment. However, the submerged areas were more extended than the present-day basin surfaces. Nowadays, the Pliocene marly deposits in the Baraolt Basin are located at 700-750 m altitude. By that time, Baraolt Mountains constituted an area of numerous emerged islands, where the flysch deposits were cropping out. Also vast areas in the eastern part of Perşani Mountains were submerged under the waters of the Pliocene lake.

At the end of Romanian, in the northern part of South Harghita the first volcanic structure (Luci - Lazu) has been completely outlined; but volcanic events continued even during Pleistocene, as shown by the thin layers of tuffs and tephra within the succession of the Middle Ciuc Basin (Fig. 3 and profile in Fig. 6).

By that time, the Cucu volcanic structure in its general lines has been also defined. In the Pilişca structure area the volcanic cones of the first stage were built up, giving birth to "backstage-type" structures.

During the volcanic calm period of the main alignment recorded at the end of Pliocene, the deposition of the upper part of the marls in the adjacent areas (especially in Baraolt Basin) was accompanied by a new shift of the volcanic activity. During this interval, the volcanic activity resulted in the formation of small volcanic structures displayed along a north-east - south-west direction.

That interval can be considered the main volcanic stage along the Bicsad - Malnaş alignment (2.2 Ma-1.4 Ma); in the same time the alkali-basaltic rocks in Perşani Mountains (Comana, Bogății Valley - Racoşul de Jos) (Figs. 1, 2). The Malnaş, Luget, and Murgul Mic structures had mainly an effusive-type activity. 


\section{PALEOGEOGRAPHICAL EVOLUTION DURING THE EARLY AND MIDDLE PLEISTOCENE}

The tectonic regime established at the Pleistocene beginning led to a series of major changes of the regional paleogeography (Fig. 4 and profile in Fig. 6). First of all, the whole area - including the two basins adjacent to the volcanic alignment Harghita, was partly uplifted (László, 1999b). Together with the neighbouring sectors (Perşani, Baraolt, Bodoc, and Ciuc Mountains) gently uplift in parallel with the reactivation of volcanism along the main alignment of South Harghita. These events changed the sedimentation in the adjacent basins towards, a fluviatilelacustrine one and gradually favoured a continental one. The large amount of volcanic material emitted by the still active volcanoes gave birth to the upper volcanoclastic complex (László \& Kozák, 1998a, b) and played a major role in the basin filling.

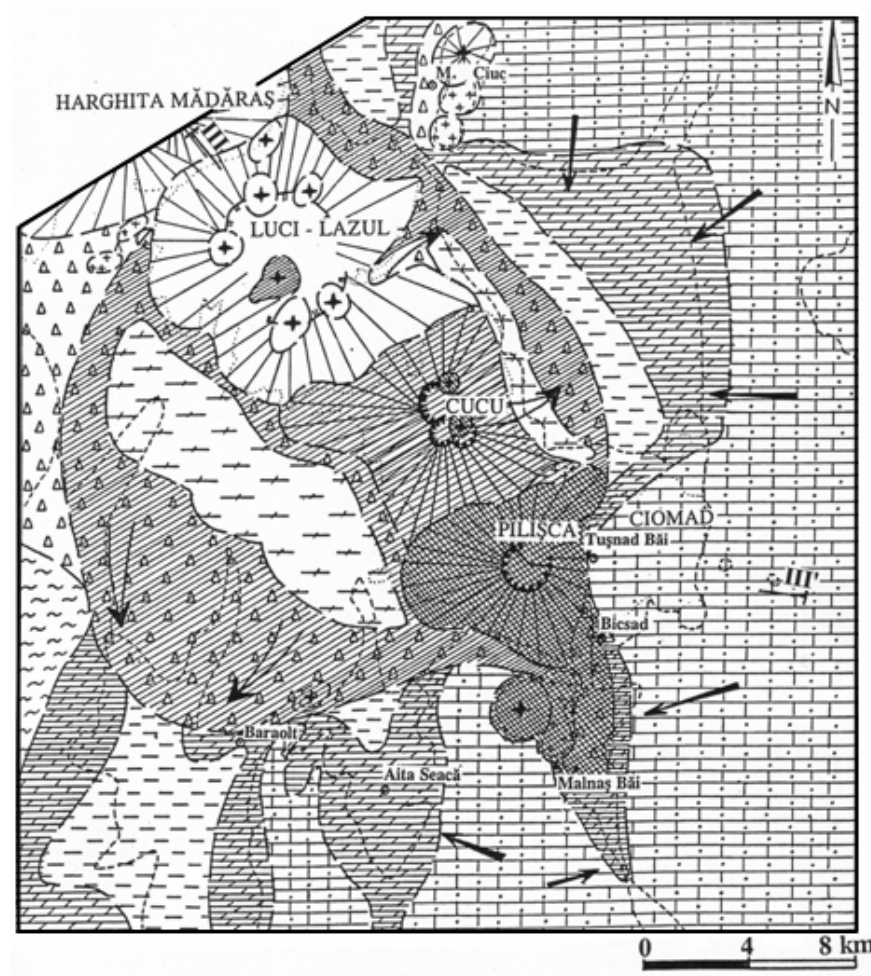

Fig. 4. Paleogeographical sketch of the South Harghita area and the adjacent areas during the Early Pleistocene. Same legend as for Fig. 1.

The formation of this final, very heterogeneous volcanoclastic complex was mainly a subaerial process, especially well defined in the Baraolt Basin, genesis that favoured the rapid erosion towards the peripheral areas (i.e. the lower altitude sectors in the Baraolt and Ciuc Basins). This phenomenon led to the formation of the main valleys of the hydrographic system of the two slopes of the volcanic chain (Baraolt, Ozunca, Cormoș, Pârâul Băilor, and Valea Mare creeks).

During Early Pleistocene, the volcanic material was mainly generated by Pilişca structure, phase II (László, 1999b) - with a particularly intense activity, and Cucu structure. The lithological succession in the Middle Ciuc Basin, indicates a continual activity for the Luci-Lazu structure and the North Harghita region passed through a calm volcanic stage (Kusko et al. 1988, not published). At the top of succession thin horizons of tuffitic and tephra material are known. Locally (e.g., Vasfuvódomb area) intense postvolcanic phenomena (geyserites, opals) took place.

In the Baraolt Basin terrigenous lithons are interlayered within the upper volcanoclastic complex. They do not represent stratigraphic markers, but indicate interruptions in the activity of major volcanic structure. As an exception, one can note the sedimentary deposits with diatomite interlayers in the median part of the upper volcanoclastic complex, and the pumice deposits at its top (Fig. 7).

The formation of lacustrine environments, respectively the diatomite genesis along the two slopes of the main volcanic alignment (Luci-Lazu and $\mathrm{Cucu}$ structures) was probably synchronous with the restoration of volcanic activity in the southern end of the Harghita Mountains (Pilişca and Ciomad). Hornblende - biotite andesite volcanoclastics were deposited during the Early and Middle Pleistocene, above the diatomites (László, 1999b).

The formation of the lacustrine environments in the close vicinity of the volcanic cones was favoured by the process of sinking of the slopes of the volcanic alignment. The sinking probably represented a movement that compensated the large volume of extruded volcanic material.

The diatomite-generating environment points to the alignment of thermal springs, and the location of postvolcanic phenomena along the southwestern border of the volcanic chain.

Pumice deposits represent another significant lithological sequence within the upper volcanoclastic complex. They are located along an alignment that is closer to the axis of the main volcanic chain than the diatomite deposits. Pumice was also deposited in a fluviatile-lacustrine environment as diatomite done, or it can be found in debris flows. It crops out in the upper part of several parallel valleys on the western slope of the main volcanic structures (Păstrăvilor, Gherend, Coşagul Mic, Coşagul Mare, and Herculian valleys) (Fig. 7). The pumice ejection is related to a paroxysmal activity. It records tilting of the slopes adjacent to the main volcanic structures, where lakes formed again for short periods. The inclinations of the diatomite layers with $5^{\circ}-7^{\circ}$, or even $12^{\circ}$, towards the axis of the main volcanic chain $\left(3^{\circ}-5^{\circ}\right.$ for the pumice horizon) also plead for the sinking of the growing volcanoes.

Fragments of pumice were also identified on the eastern border of the volcanic alignment, next to $\mathrm{Cucu}$ and Pilişca structures at the periphery of Ciuc Basin, as reworked material in younger deposits.

During the Middle Pleistocene the morphology of the Harghita main volcanic chain was basically similar to the present one. The Luci-Lazu, and Cucu structures had the same outlines, but without the present-day erosion. The volcanic activity in the structures from the Malnaş - Bicsad group had already ended in the Early Pleistocene $(\sim 1.4 \mathrm{Ma})$ (Michailova et al., 1983), thus the morphology of volcanoes remained unchanged. Pilişca structure terminated activity (around 0.7 Ma). Starting with the Middle Pleistocene the active volcanism was shifted towards the Pilișca, Ciomad, and their peripheral structures (Dealul Mare, Puturosul Mountain, Cetăţii Hill) (Fig. 5 and profile in Fig. 6).

A general uplift of the intramontaineous basins and their adjacent areas took place during this interval. As a result, the Pliocene deposits occuring at 150-200 $\mathrm{m}$ altitude in the centre of Baraolt Basin crop out around 650-700 $\mathrm{m}$ at its periphery (e.g., Aita Seacă sector). At the end of Middle 
Pleistocene, the submerged area in Baraolt Basin was restrained to the central sector between the localities Vârghiş, Căpeni, and the junction of Olt river with Cormoş brook. The corresponding sediments are very rich in mammals, used for the lithostratigraphical assignment (Samson \& Rădulescu, 1969, 1995).

During the Early Pleistocene, the Lower Ciuc Basin gradually reduced its area of, as shown by the continental deposits found in numerous drill samples. The lake restrained along a narrow alignment defined by the localities Sânsimion - Tuşnadul Nou. Coarse torrential detrital rocks proceeding from the eastern border of the basin gradually replaced the lacustrine deposits (Kusko et al., 1988, not published).

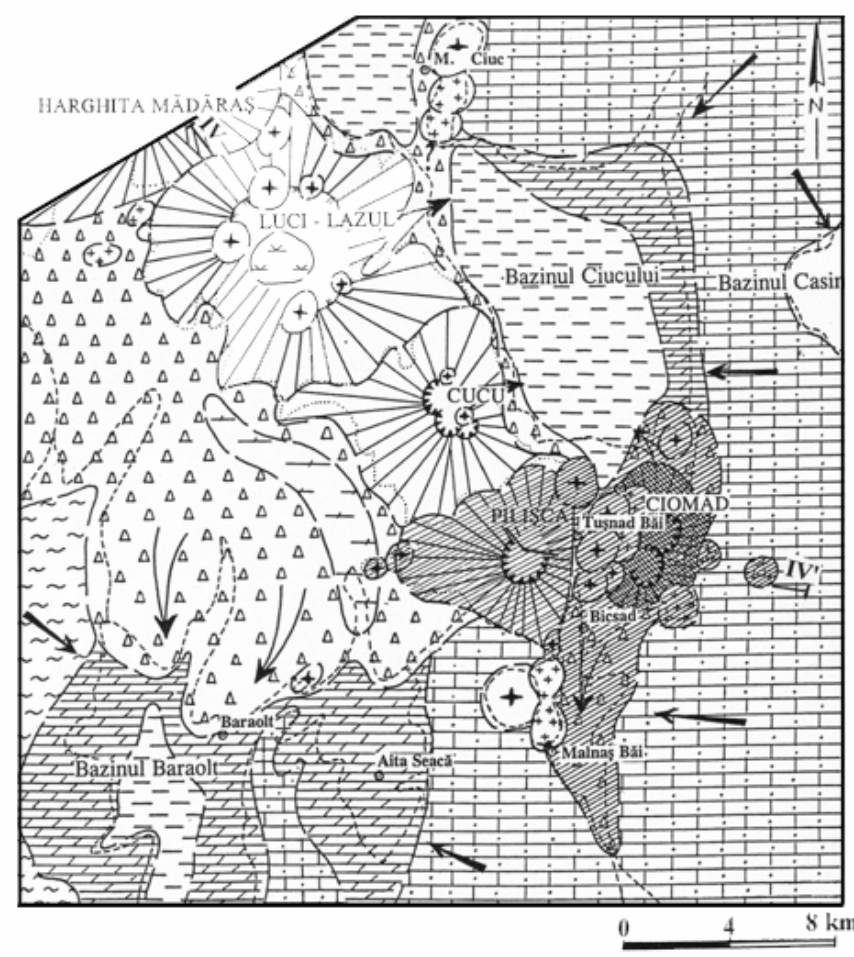

Fig. 5. Paleogeographical sketch of the South Harghita area and the adjacent areas during the Middle and Late Pleistocene.

\section{DATA ON THE PALEOGEOGRAPHICAL RECONSTRUCTION OF THE SOUTHERN EXTREMITY OF HARGHITA AND TUŞNAD - MALNAŞ CHANNEL}

Starting with the Middle Pleistocene, most of the geological events of paleogeographical significance were concentrated in the southern extremity of Harghita Chain. Here the volcanic activity reached its maximum during this interval, significantly influencing the sedimentation in the Lower Ciuc Basin and in the Tuşnad - Malnaş Channel (Fig. 5) and modeling the landscape even in further areas, south from Sfântu Gheorghe locality (Fig. 1).

Recently obtained geological data concerning the Bicsad - Malnaş - Sfântu Gheorghe area and the Lower Ciuc Basin (László et al., 1997b, 1999b) was used for a reconstruction of the events during the Middle and Late Pleistocene. In Pilişca and Ciomad areas, the geological phenomena undoubtedly show a direct relationship with the volcanic eruptions in the Ciomad and Pilişca structures, that allows a coherent paleogeographical reconstruction.
Based on radiometric data, it can be stated that the paroxysmal activity in the Ciomad structure took place during the Middle Pleistocene (Szakács \& Seghedi., 1995a, b). Simultaneously the activity in the Pilişca structure (phase II) was in progress. The formation of the main volcanoclastic cones of the Ciomad structure represented the first impact on the landscape. As a secondary effect, the connections between the Lower Ciuc Basin and the Bicsad Malnaş small basin were closed due to the formation of a natural dam of volcaniclastics in Tuşnad region, in-between the two depressionary areas. This event lead to the rise of the water level behind the dam; thus, in the Lower Ciuc Basin and probably also in the Middle Ciuc Basin the sedimentation registered a new submerged stage. In the southern part of the basin, on the top of vocanoclastic deposits, quartz sands interlayered with andesitic sands and volcanic lapilli 40-45 m thick have formed. They are well exposed in the quarries south from Tuşnadul Nou locality (László, 1999b, Fig 45). Stratigraphically age of the andesitic sand deposit is younger than that of the volcanoclastic cones of the Ciomad structure $\sim 0.6 \mathrm{Ma}$ (for Haromul Mic and Haromul Mare). But the age of the volcanic material that is contained by the sandy complex is still much younger. The radiometric data obtained on various rock types of materials can be estimated as being less than 0.22 Ma (Szakács et al., 1994). Thus, the formation of these deposits can be assigned to the Middle Pleistocene, probably starting with the Mindel - Riss interglacial but not excluding a younger age. The data obtained by Rădulesco \& Samson (1985) on mammal fauna indicate that the sandy complex is not older than the Riss glacial stage.

Downstream from the Ciomad structure, within the Bicsad - Malnaş small basin following a sedimentation hiatus (László, 1999b), a succession of sands, tuffites and a thick pile of epiclastites and andesite sands - the latter proceeding from the Pilişca and especially Ciomad structures - formed. At the top, a layer of brownish diluvial clayey-sandy deposits with pebbles, sandstones, marls and volcanic rocks deposited. These sediments covered the whole depressionary area, and currently occur on both slopes of Olt Valley. According to Liteanu et al. (1962) their age is Villafranchian - Mindel.

Taking into account the age established for the Malnaş andesite (2.2 - $1.45 \mathrm{Ma}$, Michailova et al., 1983) and because the detrital deposits rest on the top of the volcanic rocks, we assign them to the upper part of the Early Pleistocene, and to the Middle Pleistocene. Considering constituents of the andesitic sand, it can be said that they proceed almost exclusively from the Ciomad and Pilişca structures. This horizon can be attributed to the Mindel Riss interval. A similar assignment belongs to Bandrabur (1971), based on lithostratigraphical arguments.

As a summary, the sandy, tuffitic deposits located between the marls (in the base) and the andesitic sand (in the top) are assigned to the Early Pleistocene - Middle Pleistocene boundary, and they represent the eruption products of the Pilişca and Ciomad structures.

By analogy with the similar continental deposits from Sfântu Gheorghe gulf - containing mammals (Samson et al., 1969), and according to Peltz (1971b) we attribute the upper part of the lithological succession to the Würm glacial stage.

The subsequent events of the Middle and Late Pleistocene in the Tuşnad - Sfântu Gheorghe region can be best deciphered by the study of the lithological succession 


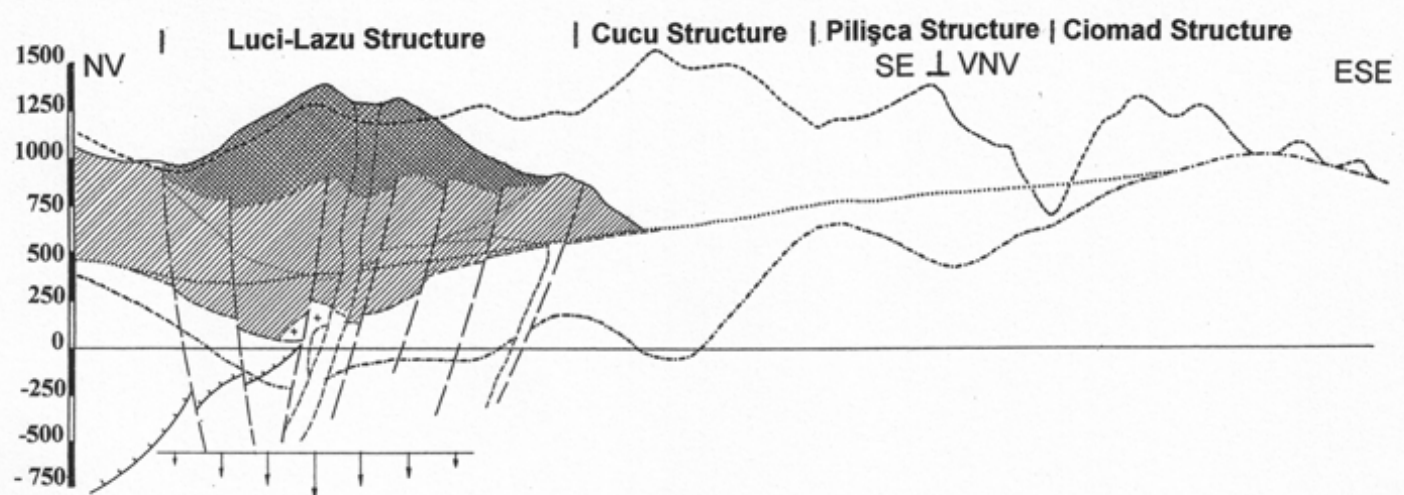

\section{II - II'}

Upper Pliocene

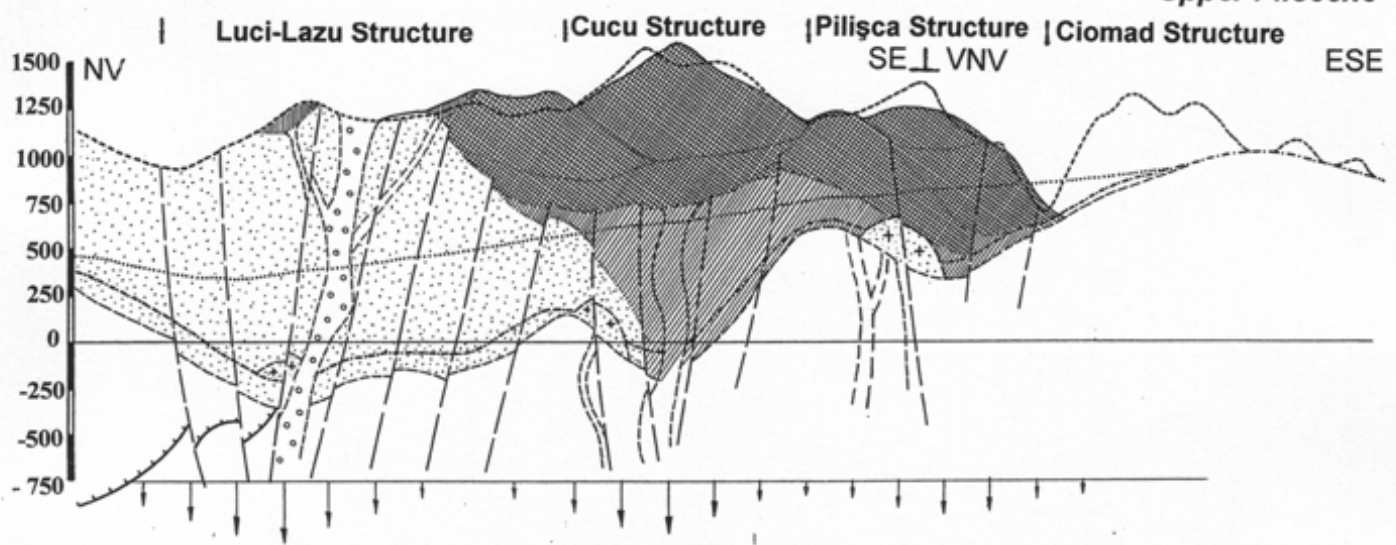

III - III'

Low Pleistocene

|Cucu Structure

|Pilişca Structure I Ciomad Structure
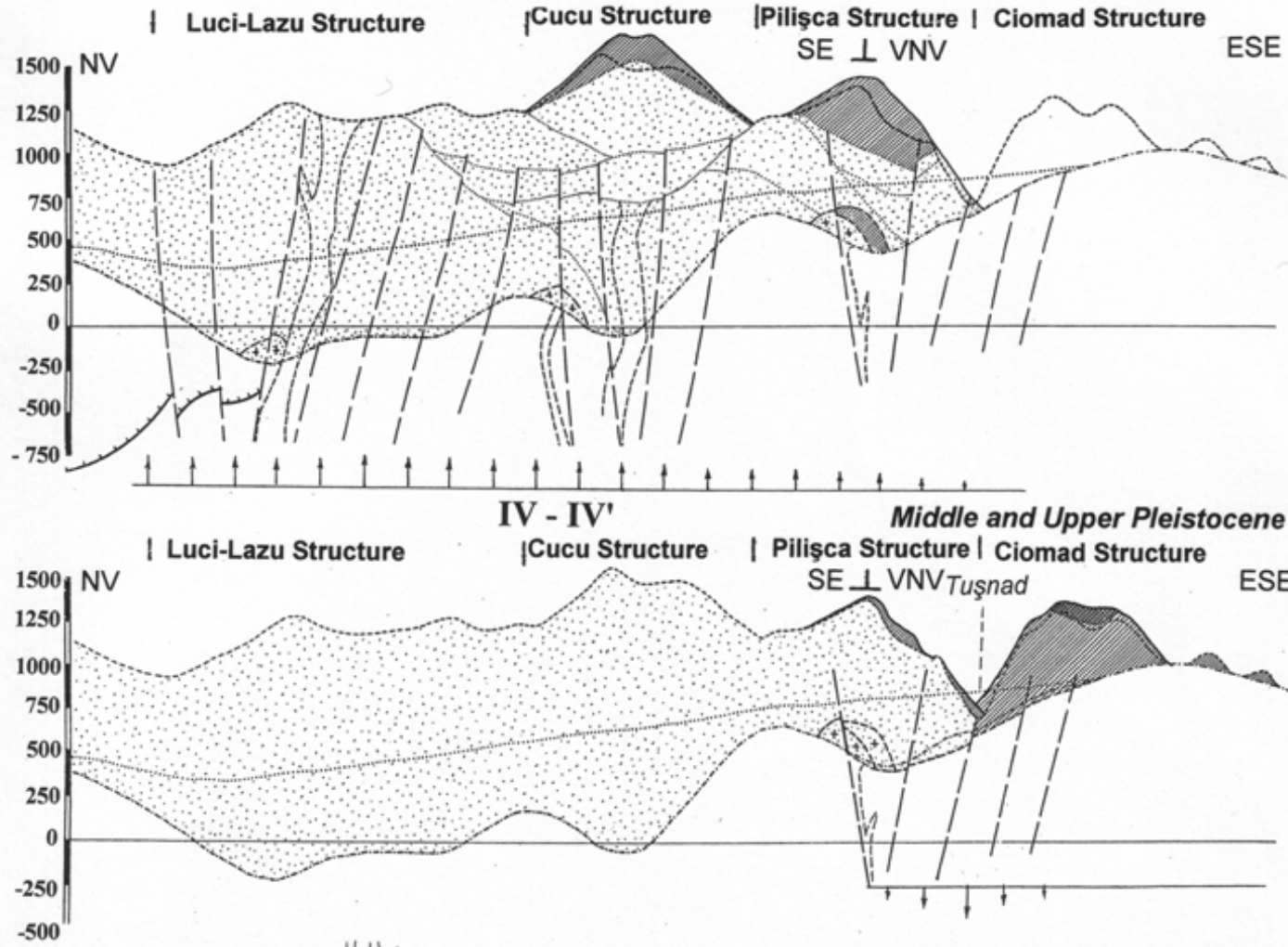
1. $2 . / 3 .++$
4. $10 \%$
5. $6 ., 7$
8. 9.
10.
11.

Fig. 6. Geological profiles through the median area of the South Harghita volcanic alignment; the volcanic active areas during the mentioned time intervals are marked (Low Pliocene, Upper Pliocene (Romanian),

Early Pleistocene, Middle and Upper Pleistocene). 1. overthrust; 2 fault; 3. intrusive, subvolcanic structures; 4. volcanic vent; 5 . original morphology of the pre-volcanic basement; 6. present-day morphology of the pre-volcanic basement; 7. proposed morphology of the pre-volcanic basement during the studied time interval; 8. present-day morphology of the volcanic chain; 9. inactive area of the volcanic chain; 10. active area of the volcanic chain (stage I); 11. active area of the volcanic chain (next stage). 
cropping out in the sand quarry from Zoltan (László et al., 1997b, Fig. 3B).

The succession in the Zoltan quarry is typically a regressional one, showing a gradual shallowing from lacustrine to deltaic, fluviatile and finally subaerialcontinental environments, the latter with solifluction features. The unsorted pebble layer at the middle part of the succession, which has a torrential origin and was deposited very rapidly, represents the single exception.

This horizon within may be directly related to the breakdown of the volcanoclastic dam from Tuşnad Băi. The event might have been the result of a new short episode of explosive volcanism of high intensity belonging to the last stage of the Ciomad structure. This explosion released relatively reduced amount volcanic lapilli, pumice and volcanic bombs associated with high amounts of gases. The cause was probably the rise of the water level behind the natural dam of volcanic agglomerates, which favoured the water infiltration at the lower part of the Ciomad volcanic edifice, leading to violent hydroexplosions.

The presence of the first level of pumice originating from Ciomad structure beneath the andesitic sand horizon is an argument for this model.

The youngest age that can be attributed to this explosion of the Ciomad structure is related to the radiometric data on pumice, i.e. $35,000-40,000$ years; it represents the last volcanic event that could be identified and radiometrically dated. The ${ }^{14} \mathrm{C}$ results of Moriya et al. (Moriya et al., 1996) refer to the formation of the last pumice horizon. If we accept that at least two pumice layers there are at Bicsad, Zoltan and Tuşnad Sat, we may suggest the age of 0.1-0.15 Ma for the first layer (Szakács et al., 1994), after the Mohoş and Sf. Ana craters have been finally outlined. This age is in agreement with the results of Samson et al. (1969) on mammal fauna identified in the area.

Based on K-Ar radiometric ages, the breakdown of the volcanoclastic dam from Tuşnad Băi may be appreciated between $100,000-35,000$ years, corresponding to the RissWürm interglacial and the beginning of the Würm glacial stage.

The breakdown led to the partial displacement of the sediments in the Ciuc Basin, and the installation of peat-bog environments, well developed in the neighbouring of Sântimbru and Sânsimion (Lower Ciuc Basin), and Ciaracio and Ciceu (Middle Ciuc Basin) localities respectively.

The sedimentation pattern and the paleogeographical evolution of the Sfântu Gheorghe gulf during the Middle and Late Pleistocene were highly influenced by the destruction of the volcanoclastic dam (Fig. 1). The connections between the Ciuc Basin and Bârsa Depression, interrupted during the Middle Pleistocene due to formation of the two volcanic structures, were finally retaken at the end of the Late Pleistocene, probably during the Würm glacial.

During the Middle Pleistocene, the last effects of regional tectonics were represented by an oscillation of the flysch structures in Baraolt area and Sfântu Gheorghe gulf. A more prominent uplift trend was noticeable in the Tuşnad Băi - Aita Seacă area, while south from Sfântu Gheorghe the region sank rapidly, as proven by the gradual regression of the waters from Sfântu Gheorghe Basin and Bicsad towards the centre of the Bârsa Depression. This regression may be also correlated with the opening of the Augustin - Racoşul de Jos Channel from Perşani Mountains.
The amount of volcanic material proceeded from Ciomad and Pilişca structures that were deposited in the Lower Ciuc Basin, the Bicsad - Malnaş small basin, and Sfântu Gheorghe gulf respectively suggests an original volume of volcanic rocks at least twice as large as that known in the present-day Ciomad structure.

\section{CONCLUSIONS}

The paleogeographical and morphological evolution of the Baraolt - South Harghita - Ciuc area has been the result of the tectonic events, volcanic activity and the sedimentation patterns - i.e. the gradual basin filling vs. erosional processes - that took place during the last 5-6 million years.

The volcanic events, respectively the formation of the stratovolcano structures along the main South Harghita volcanic chain played a major role in the modelling of the regional morphology. With a few exceptions, the smallsized magmatic structures paralleling the East-Carpathian orogen have been covered by the main stratovolcanoes. These small structures produced local variations on the morphology and on the general outline of the area, on both sides of the main volcanic chain.

During the first part of the Pliocene - Pleistocene interval, the dominant factor of paleogeographical modelling was represented by the regional tectonics; afterwards - in the Baraolt - Harghita - Ciuc area - there was a shift of causality towards the volcanic activity, sedimentation features and basin filling -erosional processes within the intramountaineous basins.

The beginning of the regional paleogeographical changes was marked by the tectonic activation of the EastCarpathian structures in the foreland of the CrystallineMesozoic Unit. The timing of the basin evolution along the volcanic chain can be correlated with the gradual shift towards southeast of the volcanism.

The new structural-tectonic setting outlined at the beginning of the Pliocene allowed the formation of crests and summits parallel with the East-Carpathian orogen, respectively the set up of river basins parallel to those of Cormoş, Vârghiş, Homoroade and Târnava Mare.

During the Pliocene, a distinctive general sinking trend of the alpine structures was recorded in the Baraolt - South Harghita - Ciuc depressionary area, while the sediments that were accumulated in the intramontaineous basins showed clear transgressional features. From time to time, the formation of the sedimentary deposits was disturbed by the generation of volcanoclastic, tuff and tuffite layers that point out the paroxysmal stages of the South Harghita volcanism.

Along a diagonal direction within the middle sector of the Baraolt-Harghita-Ciuc depressionary area the main volcanic alignment formed. It consisted of stratovolcanic structures built up mainly of volcanoclastics, and subordinately lava flows. The main volcanic structures (Luci, Cucu, Mitaci, Pilişca) were outlined, as a continuos alignment of central-type volcanic edifices separating two distinctive catchments in the area, starting with the Pliocene.

The tectonic regime established at the beginning of the Pleistocene firstly provoked a general uplift of the whole area, including the partial uplift of the two basins next to South Harghita volcanic chain. These events have determined the nature and type of sedimentation in the 


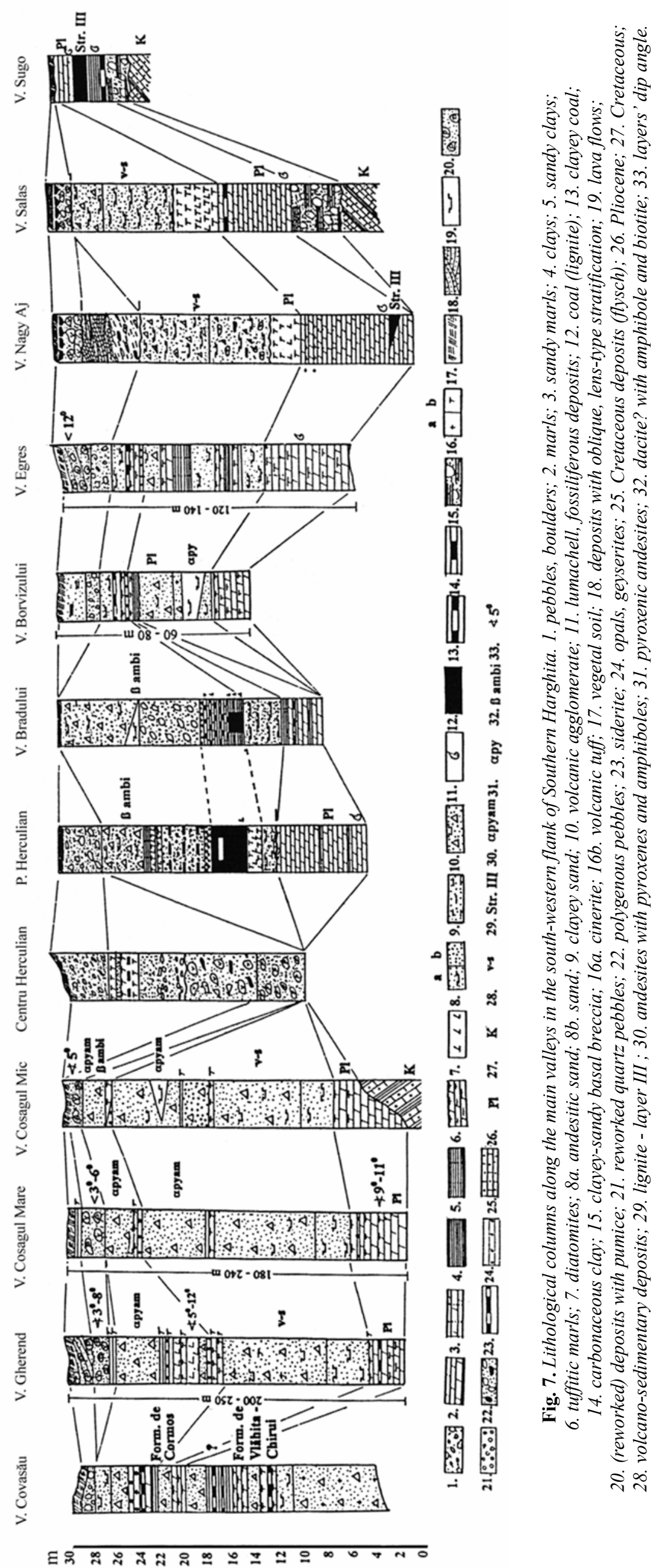


adjacent basins, which gradually passed from a basinal, to a fluviatile-lacustrine one, ultimately favouring the installlation of an environment with continental features.

Concomitantly, the reactivation of tectonic movements during the Early Pleistocene was the starting point of a new paroxysmal volcanic stage, with more intense activity in the southern parts of the South Harghita main volcanic alignment. The immediate results were represented by the disconnection of the Ciuc and Bârsei intramontaineous basins, as well as by the gradual retreat of the waters in the southwestern sectors of the Baraolt Basin.

During the Middle and Late Pleistocene important paleogeographical events took place only in the southeastern areas of the volcanic alignment. The volcanic products of the Pilişca structure and especially those of the Ciomad volcano built-up the natural dam of agglomerates from Tuşnad Băi. As a consequence, the water level behind the dam raised and thus the lacustrine environment was maintained in Ciuc Basin until the Late Pleistocene.

The last volcanic events during the Late Pleistocene were relatively short, had a phreatic-explosive nature and they manifested violently in the Ciomad structure. Among the main effects, the breakdown of the volcanoclastic dam from Tuşnad Băi, and the partial levigation of sediments from the Lower Ciuc Basin to areas as far as southwards Sfântu Gheorghe can be mentioned.

\section{R E F E R E N C E S}

Airinei, Şt., Georghiu, C., Iancu, I. 1965, Considerații asupra evoluţiei geologice şi geomorfologice a Depresiunii Ciucului. Comunicări geologice, I: 19-37.

Andreescu, I., Rădan, S., Rădan, M. 1987, Magnetobiostratigraphy of the middle-upper Neogene and Pleistocene deposits of Romania. Ann. Inst. Geol. Hung. (A Magyar Álami Földtani Intézet 1987-es évkönyve), LXX: 343-349.

Atanasiu, I. 1939, Zăcăminte de minereu de fier din regiunea Vlăhița-Baraolt (Harghita). Dări de Seamă ale Institutului Geologic Român, 19: 124-146.

Băicăințan, N. 1981, Phenomenes periglaciaires pleistocenes dans le secteur central des monts de Bodoc. Revu roumain de geologie, geophisigue et geographie, 25 (1):157-166.

Bandrabur, T. 1963, Contribuții la cunoaşterea geologiei şi hidrogeologiei depozitelor cuaternare din bazinul $\mathrm{Sf}$. Gheorghe. Dări de Seamă ale Şedințelor Comitetului. Geologic, L (2): 415-431.

Bandrabur, T. 1971, Intinerary: Braşov-Coşeni-Sf. Gheorghe-Malnaş-Bicsad-Tuşnad-Braşov. Guidebook for excursion Prahova Valley - Braşov Basin, INQUA, 26-29.

Bandradur, T., Roman, Ş. 1972, Contribuții privind cunoaşterea cuaternarului depresiunii intracarpatice a Ciucului. Studii tehnice şi economice, seria Geologia Cuaternarului, 4: 56-72.

Bányai, J. 1922, Studiul geologic asupra flancului de vestmijlociu al munților Harghita. Dări de Seamă ale Institutului Geologic Român, X: 1-13.

Bányai, J. 1927, A felső Olt-szorosok geológiai vizsonyai. Cluj Napoca, Erdélyi Irodalmi Szemle, 379-387.

Bányai, J. 1929, A Hargita vulkanikus kőzeteinek elterjedése. Emlékkönyv, Székely Nemzeti Múzeum, Cluj Napoca, Minerva Irod. és Nyomdai Müintézet, 503-507.
Bányai, J. 1932, A Hargita déli részének opallerakodásairól. Magyar Tudományos Akademia Matematikai és Természettudományi Értesitője, 49: 198-202.

Bulla, B. 1948, A két Csiki-medence és az Olt-völgy kialakúlásáról. Földrajzi Közlemények, LXXVI: 134-156.

Clain, E. \& Andriescu, G. 1978, Prospecțiuni microgravimetrice şi electrometrice pentru minereuri de fier $\hat{\imath}$ vulcanitele neogene din Munții Harghita, perimetrul Vlăhița-Chirui, Băile Homorod-Chirui. Raport I.P.G.G.Bucureşti, 46 pp.

Clain, E., Szakács, A. 1980, Prospecțiuni geologice şi microgravimetrice pentru minereuri de fier în vulcanitele neogene din Munții Harghita, perimetrul Chirui-Vîrghiş. Raport I.P.G.G. - Bucureşti.

Casta, I. 1971, Premieres données sedimentologiques sur des temoinnes de phenomenes periglaciaires quaternaires dans le bassin Brasov, Roumanie. C. R. Acad. Sc.: 272-284.

Casta, I. 1980, Les formations quaternaires de la Depression de Brasov, Roumanie. Thèse dr., Univ. d'Aix Marseilles, $256 \mathrm{pp}$.

Coteț, P. 1971, Geomorfologia regiunilor eruptive. Trăsăturile fundamentale ale reliefului Muntilor GurghiuHarghita. Studii Cercetări Geologice, Geografice şi Geofizice., Seria geografie, 18 (2).

Ghenea, C. et al. 1981, Pliocene and Pleistocene deposits in the Brasov Depression. 1-8 June, SEQS, Guidebook for the field excursion. SE QS-INQUA: 16-22, Bucharest.

Gheorghiu, C. 1956, Relațiile dintre sedimentele terțiare şi eruptivul lanțului Harghita, fenomene postvulcanice. Dări de Seamă ale Comitetului Geologic, 40: 131-137.

Iancu, M. 1965a, Depresiunea Braşovului. Unpublished $\mathrm{PhD}$ Thesis, Cluj Napoca

Iancu, M. 1965b, Terasele Oltului în Depresiunea Braşovului. Analele Universității Bucureşti. Seria Ştiințele Naturii, Geologie, Geografie: 14 (1).

Iancu, M. 1972, Masivul Bodoc. considerații geomorfologice. Aluta: 225-233.

Ionescu, F., Polonic, P., Popescu-Brădet, L., Niculin, M., Peltz, S., Scurtu, F., Teodorescu, V., Moldoveanu, M. 1984, Cercetrări complexe geologice, geofizice în vederea stabilirii perspectivei pentru minereuri de fier în zonele Sovata-Lueta-Herculian, Toplița-Mădăraş-Bixad. Raport, I.G.G., (Arh. Geolex S.A. - M.Ciuc), 84 pp.

Ionescu, F., Popescu-Brădet, L. \& Teodorescu, V., 1988, Cercetarea micromagnetică a formațiunilor vulcanosedimentare din zona de sud a munților Harghita în vederea stabilirii particularităților structurale şi sedimentologice, I.G.G.-Bucureşti, (Arh. Geolex S.A. M.Ciuc), $56 \mathrm{pp}$.

Juvigné, E., Gewelt, M., Gilot, E., Hurtgen, C., Seghedi, I., Szakács, A., Gábris, Gy., Hadnagy, Á., Horváth, E. 1994, Une eruption vieille d' environ 10700 ans (14C) dans les Carpates Orientales (Roumanie). Comptes Rendus, Acad. Sci. Paris, 318 (II): 1233-1238.

Karátson, D. 1990, Kárpati kalderák értelmezése a morfometria tükréden. Födrajzi Közlöny, 114 (3-4): 129-137.

Karátson, D., Pécskay, Z., Szakács, S., Seghedi, I. 1992, Kialudt tüzhányok a Hargitában: a Kakukkhegy. (An extinct volcano in the Harghita Mts: Mt. Cucu). Tudomány, 1: 70-79. 
Kristó, A. 1956, A Csiki-medence földtörténete. Muzeul Raional Miercurea Ciuc: 1-21.

Kristó, A. 1957, A Csiki-medencék geomorfológiai problémái. Csiki Múzeum Közleményei: 23-50.

Kristó, A. 1972a, Date cu privire la evoluția rețelei hidrografice a Oltului superior în depresiunea Ciucului. Aluta: 241-148.

Kristó, A. 1972b, Unele probleme privind delimitarea şi denumirea unităților de relief din împrejurimile depresiunilor intracarpatice ale Oltului superior. Aluta: 241-249.

Kristó, A. 1974, Unele aspecte hidrogeologice ale apelor minerale de pe teritoriul oraşului Miercurea-Ciuc şi al împrejurimilor. In: Factori terapeutici naturali din județul Harghita, Miercurea Ciuc, 124-130.

Kristó, A. 1980, Csikszereda környékének geomorfológiája. Geomorfologia împrejurimilor oraşului Miercurea Ciuc. Acta Hargitensia: 273-298.

Kristó, A. 2003, A Hargita felszinalaktani jellemvonásai. A Hargita-hegység és környéke ásványvizes fürdői, Csiki Természetjáró és Természetvédö Egyesület, pp. 5-11.

Kusko, M. 1983, Zăcămîntul de lignit de la Sf. Gheorghe si pozitia lui stratigrafică în suita depozitelor pliocene ale bazinului intramontan al Tării Bîrsei. Studii şi Cercetări Geologice Geofizice, Geografice, 28:125-131.

Kusko, M., Matei, V., Buda, A., László, A., Fekete, T., Györfy, Zs. 1988, Raport geologic. Prospecțiuni geologice pentru lignit în depozitele pliocen-pleisticene din Depresiunea Ciucului, zona Miercurea Ciuc - Mihăileni, județul Harghita. I.P.G.G., I.P.E.G. Harghita. (Arh. Geolex S.A. - M. Ciuc).

László, A. 1999a, Evoluţia tectonică a ariei Baraolt Harghita de Sud - Ciuc reflectată prin succesiunea evenimentelor vulcanice din Harghita de Sud, din perioada pliocen - pleistocenă. Acta (Muzeul Național Secuiesc, Sf. Gheorghe), 11-22

László, A. 1999b, Studiul geologic al structurilor vulcanice din partea sudică a Masivului Harghita. Unpublished PhD Thesis, Univ. Babeş - Bolyai, Cluj - Napoca, 358 p.

László, A. 2000a, Contributions to the Paleogeographical evolution of the Southern Harghita and the Neighbouring Areas during the Pontian-Pleistocene. Anuarul Institutului Geologic al României, 72 (Special Issue): 45.

László, A. 2000b, Date asupra paleogeografiei ariei Harghita de Sud şi a sectoarelor limitrofe, de la sfârşitul Ponțianului până în Pliocenul superior. Acta (Muzeul Național Secuiesc, Sf. Gheorghe), 9-20.

László, A. 2001, Date asupra evoluției paleogeografice a ariei Harghita de Sud şi a sectoarelor limitrofe, în Pleistocen. Acta (Muzeul National Secuiesc, Sf. Gheorghe), $9-22$.

László, A. 2003, Spatial evolution of the Neogene volcanism in Harghita Mountains in connection with the tectonic events from the Carpathian bent area (Romania). Abstract Vol. of the $5^{\text {th }}$ Symp. Baia Mare Branch of the Geological Society of Romania, 73: 25.

László, A., Kozák, M., Pécskay, Z. 1995, Cercetări preliminare vulcanologice si petrografice asupra magmatitelor pliocene din partea estică a Bazinului Baraolt. Abstracts book, Symposium on Petrometallogeny, "Babes-Bolyai" Cluj-Napoca, pp. 21, Cluj-Napoca.

László, A. \& Dénes, I. 1996, Elemente structural-tectonice pentru un model evolutiv în zona bazinului Baraolt Acta (Muzeul Național Secuiesc, Sf. Gheorghe), 9-16.
László, A., Kozák, M. \& Püspöki, Z. 1996, Szerkezeti vulkanológiai és magmás kozettani vizsgálatok a Barótimedence keleti részén. Acta (Muzeul Național Secuiesc Sf. Gheorghe), 17-32.

László, A., Kozák, M., Pető, A.K. 1997, Korrelatív eseménytörténeti rekonstruktió a Baróti-medence és a Dny - Hargita pontusi - pleisztocén vulkáni - vulkanoszediment képzödményei alapján. Acta (Muzeul Naţional Secuiesc, Sf. Gheorghe), 9-20.

László, A. \& Kozák, M. 1998a, Pliocene-Pleistocene volcano-sediment levels in the young sediment series of the Baraolt basin. Studia Universitatis Babeş-Bolyai, 13 (2): 101-118.

László, A. \& Kozák, M. 1998b, Pliocén - pleisztocén vulkanoszediment szintek a Baróti-medence fiatal üledéksorában. Acta (Muzeul Naţional Secuiesc, Sf. Gheorghe), 19-30.

László, A., Dénes, I. 1998, Date structural - tectonice oferite de imaginea de satelit, pentru zona vulcanitelor din Harghita de Sud şi a bazinelor limitrofe, Baraolt şi Ciuc. Acta (Muzeul Naţional Secuiesc, Sf. Gheorghe), 9-18.

László, A. \& Kozák, M. 2003, General features of the peripherial magmatic structures along the main volcanic alignment in the Harghita Mountains (Eastern Carpahians, Romania). Abstract Vol. of the $5^{\text {th }}$ Symp. of the Baia Mare Branch of the Geological Society of Romania, 73: 25.

Liteanu, E., Mihăilă, N. \& Bandrabur, T. 1962, Contribuții la studiul cuaternarului din Bazinul mijlociu al Oltului (Bazinul Baraolt). Studii şi Cercetări Geologice, VII (3-4): 48-51.

Michailova, N., Glevasovskaja, A., Sykora, V., Nestianu, I., Romanescu, D. 1983, New paleomagnetic data for the Călimani, Gurghiu and Harghita volcanic Mountains in the Romanian Carpathians. Anuarul Institutului Geologic şi Geofizic, 63: 101-111.

Moriya, I., Okuno, M., Nakamura, T., Ono, K., Szakács, A., Seghedi, I. 1996, Radiocarbon ages of charcoal fragments from the pumice flow deposit of the last eruption of Ciomadul volcano, Romania. Summaries of Researches using $A M S, 7: 255$.

Patrulius, D., Mihăilă, N. 1966, Stratigrafia depozitelor cuaternare din împrejurimile Braşovului şi neotectonica Depresiunii Bîrsei. Anuarul Com. Stat al Geologiei, 35: 259-298.

Peltz, S. 1970a, Observații asupra paleogeografiei teritoriului lanțului eruptiv Călimani-Gurghiu-Harghita în cursul Pliocenului (II). Studii şi cercetări geologice, geofizice şi geografice, seria Geologie, 15: 2-12.

Peltz, S. 1970b, Contributii la cunoașterea formațiunii vulcanogen-sedimentare pleistocene din sudul munților Harghita şi nord-estul bazinului Baraolt. Dări de Seamă ale Instituluilui Geologic. Seria Tectonică şi Geologie Regională, LVII: 173-189.

Peltz, S. 1971a, Erupții şi structuri vulcanice. Buletinul Geologic M.M.P.G., 5 (2): 2-5.

Peltz, S. 1971b, Contribuții la cunoaşterea formaţiunii vulcanogen - sedimentare pleistocene din sudul munților Harghita şi nord-estul bazinului Baraolt. Dări de Seamă ale Institutului Geologic şi Geofizic, 57 (5): 173-189.

Peltz, S., Seghedi, I., Grabari, G., Popescu, G. 1987, Strontium isotope composition of the volcanic rocks from the Călimani, Harghita and Persani mountains. Dări de Seamă ale Institutului Geologic şi Geofizic, $72-73$ (1): 309-321. 
Pécskay, Z., Szakács, S., Seghedi, I., Karátson, D. 1992, Új adatok a Kakukkhegy és szomszédsága (Dél - Harghita, Romania) geokronológiai értelmezéséhez. Földtani Közlöny, 122 (2-4): 265-286.

Pécskay, Z., Edelstein, O., Seghedi, I., Szakács, A., Kovacs, M., Criham, M., Bernad, A. 1995, K-Ar dating of Neogene-Quaternary calc-alkaline volcanic rocks in Romania. Acta Vulcanologica, 7 (2): 53-61.

Pécskay, Z. 2003, K/Ar Dating of the Neogene-Quaternary magmatism in the Carpathian-Pannonian Region (CPR). Abstract Volume of the 5-th Symposium Baia Mare Branch of the Geological Society of Romania, pp. 2.

Pop, E. 1960, Mlaştinile de turbă din R.P. Română. Bucureti, Editura Academiei R.P.R., 511 pp.

Rădulesco, C., Samson, P., Mihăilă, N., Kovács A. 1965, Contribution a la connaissance de faunes de Mammiferes Pleistocene de la depression de Brasov (Roumanie). Eiszeitalter u. Gegenwart, 16: 132-188.

Rădulesco, C. \& Kovács, A. 1966, Noi contribuții la cunoaşterea faunei de mamifere fosile din Bazinul Baraolt (Depresiunea Brasov). Travaux de l' Institut de Spéologie "Emile Racovitza", 7: 22-29.

Rădulesco, C.\& Kisgyörgy, Z. 1970, Contribution a la connaissance de la faune de Mamiferes du Villafranchien inferieur de Căpeni, Vîrghis. Aluta, pp. 11-24.

Rădulesco, C. \& Samson, P. 1985, Pliocene and Pleistocene Mammalian Biostratigraphy in southeastern Transylvania (Romania). Travaux de l'Institut de Spéologie "Emile Racovitza", 24: 126-143.

Rădulescu, C. \& Samson, P.M. 1995, Review of Villafranchian s.s. faunas of Romania. II Quaternario, Italian Journal of Quaternary Sciences, 8 (2): 377-382.

Rădulescu, D.P. 1968a, Observatii asupra paleogeografiei teritoriului lantului eruptiv Călimani-Gurghiu-Harghita în cursul Pliocenului. Studii şi cercetări geologice, geofizice şi geografice, seria Geol., 13 (1): 51-57.

Rădulescu, D.P. 1968b, Apercu general sur l'evolution du volcanisme neogene en Roumanie. Annuaire $d u$ Comite d' état pour la géologie, 36: 177-184.

Rădulescu, D.P. 1973, Le volcanisme explosive dans la partie de sud-est de Monts Harghita. Analele Universității Bucureşti, 22: 7-16.

Rădulescu, D. \& Peltz S. 1968, Asupra prezentei depozitelor de lahar în Muntii Călimani-Gurghiu-Harghita. Dări de Seamă ale Comit. Stat. Geol. Inst. Geol., 54 (1): 101-109.

Rădulescu, D.P. \& Peltz, S. 1970, Observatii asupra paleogeografiei teritoriului eruptiv Călimani-GurghiuHarghita, în cursul Pliocenului şi Cuaternarului. Studii şi cercetări geologice, geografice, Seria geologie, 15 (1): 261-266.

Rădulescu, D. \& Peltz, S. 1973, Neogene Volcanism in the East Carpathians (Călimani - Gurghiu - Harghita). Guidebook Series Geol., 2AB, Symposium Volcanism and Metallogenesis, p. 24-36, Bucuresti.

Rădulescu, D., Pătrascu, S., Bellon, H. 1973, Consideratii asupra cronologiei proceselor vulcanice neogene din muntii Călimani, Gurghiu si Harghita. Dări de Seamă ale Institutului Geologic, 59 (4): 246-258.

Samson, P., Rădulesco, C. \& Kovács, A. 1969, Faunele de Mamifere şi stratigrafia cuaternarului în depresiunea Braşov. Aluta (Muzeul Județean Covasna, Sf. Gheorghe), 193-210.

Samson, P. \& Rădulesco, C. 1969, Faunele de mamifere cuaternare din bazinele Ciuc şi Borsec (jud. Harghita).
Travaux de l' Institut de Spéologie "Emile Racovitza", 8: 123-147.

Samson, P., Rădulesco, C. \& Kisgyörgy, Z. 1971, Nouvelles données sur la faune de Mammiferes du Villafranchien inferieur de Căpeni-Vîrghis (Depression de Brasov, Roumanie). Eiszeitalter u. Gegenwart, 22: 64-88.

Samson, P. \& Rădulesco, C. 1973, Les faunes de Mamiféres et la limite Pliocéne-Pleistocéne en Roumanie. Travaux de l'Instute de Speologie "Emile Racovitza", 12: 191-228.

Savu, G., M., Lubenescu, V. \& Cismaru, G. 1978, Asupra vîrstei formațiunii productive din bazinul Baraolt. Dări de Seamă ale Institutului Geologic şi Geofizic, LXV: 157-168.

Savu, M.G. 1984, Studiul geologic al regiunii cuprinse intre localitățile Filia-Vîrghiş-Baraolt-Aita-Mare-Malnaş BăiBicsad-Herculian, cu privire specială asupra depozitelor de lignit. Unpublished PhD Tesis, Univ. Bucureşti, 184 pp.

Schreiber, W.E. 1972, Incadrarea geografică şi geneza masivului Ciomadu. Studia Universitatis "Babeş-Bolyai" seria Geographia, 1.

Schreiber, W.E. 1980, Geomorfologia munților Harghita. Unpublished PhD Thesis, Univ. Cluj-Napoca, 180 pp.

Schreiber, W.E. 1994, Munții Harghita. Studiu geomorfologic. Ed. Acad. Române, Bucureşti, 124 pp.

Szakács, A. 1986, Consideraţii privind distribuția spaţială regională a mineralizaților de siderită asociate vulcanizmului neogen din lantul eruptiv CălimaniGurghiu-Harghita. Abstracts volume, Geological Symposium Gheorgheni, p. 5.

Szakács, A., 2000, Volcano typology through pictures. Anuarul Institutului Geologic al României (Special Issue), 72: 79.

Szakács, A., Seghedi, I. \& Jánosi, Cs. 1984, Considerații privind geneza acumulărilor de piatră ponce din munții Harghita de Sud. Al II-lea Simpozion Geologic. Gheorgheni (manuscript).

Szakács, A., Seghedi, I. \& Pécskay, Z. 1993, Pecularities of South Harghita Mts. as terminal segment of the Carpathian Neogene to Quaternary Volcanic Chain. Rev. Roum. Geol., Geof., Geogr. seria Geologie, 37: 21-36.

Szakács, A., Seghedi, I., Pécskay, Z., Karátson, D. 1994, Time-Space evolution of Neogene/Quaternary Volcanism in the Călimani-Gurghiu-Harghita Volcanic Chain (East Carpatians, Romania). Abstracts of the International Volcanological Congress IAVCEI, Sept. 1994, Ankara.

Szakács, A. \& Seghedi, I., 1995a, The Călimani-GurghiuHarghita volcanic chain, East Carpathians, Romania: Volcanological features. Acta Vulcanologica, 7 (2): 145-153.

Szakács, A. \& Seghedi, I., 1995b, Time-space evolution of the Neogene-Quaternary volcanism in the CalimaniGurghiu-Harghita volcanic chain. Guide to excursion B3, $X$-th RCMNS Congress Bucuresti 1995, Romanian J. of Stratigraphy, 76, Supplement 4, 24 pp.

Szakács, A. \& Seghedi, I. 1998, Premises of tephrological investigation of the Quaternary in Romania. Romanian. Journal of Stratigraphy, 77: 145-162.

Szádeczky, K.Gy. 1929, A Székelyföld képzödése. Emlékkönyv, Székely Nemzeti Múzeum. Cluj Napoca, Minerva Irod. és Nyomdai Müintézet, 491-502.

Székely, A. 1959, Az erdélyi vulkanikus hegységek geomorfológiai problémái. Földrajzi Közlemények, 3-4: 235-263.

Török, Z. 1956a, A Kelemen-havasokban, valamint a Görgény-Hargita vulkáni lánc területén található fiatal 
eruptivum geológiai kutatásának módszertani kérdései. Kolozsvári Bólyai Tud. Egyetem Emlékkönyve, pp. 68-81.

Török, Z. 1956b, Cercetări în Muntii Călimani şi Hărghita. Dări de Seamă ale Comitetului Geologic, 40: 156-160.

Török, Z. 1959, Adatok a Harghita-fürdő és a Kakukkhegy közötti terület geológiájához és a kaolin telepek képzodésének kérdéséhez. Studia Univ. "Babes Bolyai" II (1): 26-38.

Tövissi, J. 1972, Schimbările albiei Oltului la Extremitatea de sud a Munților Baraoltului. Aluta, pp. 249-260
Tövissi, J. 1974, Morfogeneza văii Oltului superior. Studia Universitatis "Babes-Bolyai", ser. Geographia, 2: 46-62.

Tövissi, J. 1997, Az Olt küszöbei. Abstracts vol. of "Geo 97” Geological Sympoium, Miercurea Ciuc, pp. 16.

Treiber, I. 1953, Cercetări geologice în Muntii Călimani şi Hărghita. Dări de Seamă ale Sed. Com. Geol., 40: 157-160.

Treiber, I. 1972, Problema rocilor piroclastice din masivul eruptiv Harghita. Studia - Geol. Mineral., 1: 21-25. 